\title{
Knowledge on Pediatric First Aid Management Among Mothers with Under Five Children in Bharatpur
}

\author{
N. Dhanasekaran, ${ }^{1}$ L. Indhumathi, ${ }^{2}$ Anu Kharel, ${ }^{3}$ \\ 'Nursing Programme, College of Medical Sciences-TH, Bharatpur, Nepal.
}

\section{ABSTRACT}

\section{Introduction}

Paediatric emergencies are the leading causes of death in children under five years of age. The toddlers, preschoolers with highest curiosity to explore, investigate and with the ability to run and play are more prone to getting injuries like fall, burns, cuts, bites, stings, poisoning, fracture, chocking, and wounds. Paediatric emergency mostly occur in home, roads and grounds. Hence the mothers are expected to be knowledgeable on paediatric first aid management. The objectives of this research are to assess the knowledge on pediatric first aid management and to find out association between the knowledge scores of mothers with under five children with selected demographic variables.

\section{Methods}

A cross sectional analytical study was conducted to assess the knowledge regarding pediatric first aid management among 165 mothers with under five children in pediatric outpatient department of College of Medical Sciences Teaching Hospital by non-probability purposive sampling technique and data was collected by using structured interview questionnaire. The data was analyzed using both descriptive and inferential statistics SPSS software.

\section{Results}

Demographic characteristics reveal that highest percentage (73.9\%) of them belong to age groups of 21 - 30 years. Majority of them belong to nuclear family and had one under five children. The mean number of correct answers in the area of bites and stings was (4.9 \pm 0.95$)$. Majority of the respondents 89 (53.9\%) had adequate knowledge. However there was significant association between knowledge score with their education status, occupation status, family income and previous source of information.

\section{Conclusions}

The findings of the study shows that most of the respondents $76(46.1 \%)$ have inadequate knowledge about pediatric first aid management. The paediatric nurses should understand the importance to enhance the knowledge of the mothers regarding the pediatric first aid health information to save the children and reduce under-five mortality rate.

Keywords: knowledge; pediatric first aid management; mothers with under five children. 


\section{INTRODUCTION}

A Child's environment plays a critical role, both in the occurrence and the severity of an injury. Most of the injuries take place in or near a child's home. As per the UNICEF report, Nepal is ranked in $59^{\text {th }}$ position i.e. $42 \%$ regarding highest under five mortality rate. Unintentional injuries claimed 1,900 deaths of Nepalese children, $13 \%$ of the child deaths which occurred between the age of 1 and 59 months. $95 \%$ of childhood injury deaths occur in low-and middle-income countries. ${ }^{1}$

Worldwide safe kids reported, in United States $40 \%$ deaths and $50 \%$ of non - fatal injuries occur in and around the home. Every year 7, 50,000 children die from injuries. Another 400 million are seriously hurt. Many injuries lead to permanent disability and brain damage. Injuries are the major cause of death and disability among young children. Some of the common causes of injury are fall, burns and scalds, drowning, stings and bites, eye injuries, fainting, poisoning, dental emergencies, nose bleeds, seizures, skin wounds and electrocution through faulty electrical appliances etc., most of the event were household injuries 35\%. The highest number of injuries occurred at the age of 5 years. $^{2}$

Children are unaware that they are exposed to the risk of accident and injuries. They should always have someone with them, mother and caretakers should be taught first aid measures to prevent and treat various accidents and injuries that occur in homes. Almost all can be prevented if mother watch their children and keep their environment safe and many would be less serious if mothers knew what to do when an injury happens. It appears that the mother know very little regarding first aid and safety measures to prevent accidents in children under 5 years of age.

Mothers have a primary role in promoting child health through preventive behaviors at home to prevent children from various accidental emergencies. A child needs his or her mother to take care him or her until he or she grows up. Injury among children is one of the most serious factors affecting the childhood health. Mothers are not providing this care alone but also need or require support from others for their practices. So, community health nurse and paediatric nurse should impart knowledge on parents to prevent accidents, and houses should also be designed and arranged in such a way to prevent pediatric home injuries. ${ }^{3}$ Hence this study aim to assess the knowledge on pediatric first aid management among the mothers with under five children.

\section{METHODS}

A cross sectional analytical study was used to assess the knowledge on pediatric first aid management among mothers with under five children in pediatric outpatient department of College of Medical Sciences Teaching Hospital, Bharatpur, 165 mothers were selected by non probability purposive sampling technique and data was collected by using structured interview questionnaire from January 2018 to February 2018 . Ethical approval was taken by the review committee and before collection of data informed consent was obtained from the respondents. The mothers who had at least one child between 0-5 years of age were included in the study. The tool consists of 35 items. Each item has four options with one correct answer. Each correct option carries 'one score' and wrong option 'zero score'. Scoring system was calculated from the total knowledge score of 
mean value, above the mean value is adequate and less than mean value is inadequate. All data collected were entered in data sheet and analyzed using the statistical software SPSS version 20.0. The collected data were planned to be organized, tabulated and analyzed by using descriptive statistics i.e. percentage, mean and standard deviation and inferential statistics. The chi- square test was used to test the association between demographic variables and knowledge scores.

\section{RESULTS}

Demographic details of the respondents: Majority of the respondents (73.9\%) belong to age groups of 21 - 30 years. $43.6 \%$ of mothers had child in the age group 3 - 4 years. Regarding the education status, only $30.9 \%$ them had received secondary level education. Majority of them were housewife and belongs to the nuclear family. Most of the mothers 38.2 $\%$ were having a monthly income between 20,000 and 30,000, $60.6 \%$ mothers had one under five children. Majority of them 39.4 $\%$ had previous knowledge through family friends and neighbours and $62.4 \%$ of under five children had no history of emergencies. (Table 1)

Table 1. Socio demographic characteristics of the respondents. $(n=165)$

\begin{tabular}{|l|c|c|}
\hline \multicolumn{1}{|c|}{ Characteristics } & Frequency & Percentage \\
\hline \multicolumn{2}{|c|}{ Age of Mother (in years) } \\
\hline$<20$ & 10 & 6.1 \\
\hline $21-30$ & 122 & 73.9 \\
\hline$>30$ & 33 & 20 \\
\hline Age of Child (in years) \\
\hline$<1$ & 20 & 12.1 \\
\hline $1-2$ & 42 & 25.5 \\
\hline $3-4$ & 72 & 43.6 \\
\hline
\end{tabular}

\begin{tabular}{|c|c|c|}
\hline 5 & 31 & 18.8 \\
\hline \multicolumn{3}{|l|}{ Education status } \\
\hline No formal education & 4 & 2.4 \\
\hline Primary education & 38 & 23.0 \\
\hline Secondary education & 51 & 30.9 \\
\hline $\begin{array}{l}\text { Higher secondary } \\
\text { education }\end{array}$ & 47 & 28.5 \\
\hline Under graduation & 20 & 12.1 \\
\hline Post graduate and above & 5 & 3.0 \\
\hline \multicolumn{3}{|l|}{ Occupational Status } \\
\hline House wife & 90 & 54.5 \\
\hline Government employed & 5 & 3.0 \\
\hline Private employed & 22 & 13.3 \\
\hline Self employed & 24 & 14.5 \\
\hline Daily wages & 9 & 5.5 \\
\hline Agriculture & 15 & 9.1 \\
\hline \multicolumn{3}{|c|}{ Family Income per month (in Rs) } \\
\hline$<10,000$ & 12 & 7.3 \\
\hline $10,001-20,000$ & 48 & 29.1 \\
\hline $20,001-30,000$ & 63 & 38.2 \\
\hline 30,001 and above & 42 & 25.5 \\
\hline \multicolumn{3}{|l|}{ Type of family } \\
\hline Nuclear & 102 & 61.8 \\
\hline Joint & 63 & 38.2 \\
\hline \multicolumn{3}{|c|}{ No of under five children } \\
\hline One child & 100 & 60.6 \\
\hline Two & 60 & 36.4 \\
\hline Three and above & 5 & 3.0 \\
\hline \multicolumn{3}{|c|}{ Previous Source of Information } \\
\hline No source of information & 16 & 9.7 \\
\hline Family, Friends, Neighbors & 65 & 39.4 \\
\hline Newspaper, Magazine & 21 & 12.7 \\
\hline TV, Radio, Internet & 63 & 38.2 \\
\hline \multicolumn{3}{|c|}{ Child Ever Faced an Emergencies } \\
\hline Yes & 62 & 37.6 \\
\hline No & 103 & 62.4 \\
\hline
\end{tabular}


Item wise distribution of mean and SD of knowledge scores shows that out of the eight areas related to pediatric first aid management reveals that, highest mean score in the area of "Bites and Stings" (4.9 \pm 0.95$)$ and "General information about pediatric first aid" (4.1. \pm 1.35 ), However lowest mean score was obtained for "Prevention and complication" $(1.47 \pm 0.84)$. (Table. 2$)$

Table 2. Item wise distribution of mean and standard deviation on knowledge of pediatric first aid management. $(n=165)$

\begin{tabular}{|l|c|c|c|}
\hline \multicolumn{1}{|c|}{$\begin{array}{c}\text { Knowledge } \\
\text { domain }\end{array}$} & $\begin{array}{c}\text { Max } \\
\text { Score }\end{array}$ & $\begin{array}{c}\text { Min } \\
\text { Score }\end{array}$ & $\begin{array}{c}\text { Knowledge } \\
\text { score of Mean } \\
\text { 土 SD }\end{array}$ \\
\hline $\begin{array}{l}\text { General } \\
\text { information about } \\
\text { pediatric first aid }\end{array}$ & 6 & 0 & $4.1 \pm 1.35$ \\
\hline Burns & 4 & 0 & $2.8 \pm 1.02$ \\
\hline Drowning & 4 & 0 & $2.7 \pm 0.90$ \\
\hline Injuries & 5 & 0 & $3.1 \pm 1.02$ \\
\hline Poisoning & 3 & 0 & $2.7 \pm 0.63$ \\
\hline Choking & 4 & 0 & $2.8 \pm 0.97$ \\
\hline Bites and Stings & 6 & 2 & $4.9 \pm 0.95$ \\
\hline $\begin{array}{l}\text { Prevention and } \\
\text { Complication }\end{array}$ & 3 & 0 & $1.47 \pm 0.84$ \\
\hline
\end{tabular}

Majority of the respondents 89 (53.9 \%) had adequate knowledge and 76 (46.1\%) respondents had inadequate knowledge on pediatric first management. (Table 3)

Table 3. Knowledge of pediatric first aid management among mothers with under five children. $(n=165)$

\begin{tabular}{|l|c|c|}
\hline $\begin{array}{c}\text { Level of Knowledge } \\
\text { on pediatric first aid } \\
\text { management }\end{array}$ & Frequency & Percentage \\
\hline Inadequate & 76 & 46.1 \\
\hline Adequate & 89 & 53.9 \\
\hline
\end{tabular}

There is significant association between knowledge of pediatric first aid management and education status $(\mathrm{P}=0.007)$, occupational status $(\mathrm{P}=0.01)$, family income $(\mathrm{P}=0.002)$ and the previous source of information $(\mathrm{P}=0.001)$. There is no significant association between knowledge of pediatric first aid management and age of mothers $(\mathrm{P}=0.30)$, Age of child $(\mathrm{P}=0.36)$, Type of family ( $\mathrm{P}=0.74)$, Numbers of under five children $(\mathrm{P}=0.24)$ and Child's history of emergencies $(\mathrm{P}=0.85)$. (Table 4)

Table 4. Association between the respondent's level of knowledge and Socio-demographic variables.

\begin{tabular}{|c|c|c|c|c|}
\hline \multirow{2}{*}{ Characteristics } & \multicolumn{2}{|c|}{ Level of Knowledge } & \multirow{2}{*}{$\begin{array}{c}\chi^{2} \\
\text { value }\end{array}$} & \multirow{2}{*}{$\begin{array}{c}P \\
\text { value }\end{array}$} \\
\hline & Inadequate & Adequate & & \\
\hline \multicolumn{5}{|c|}{ Age of Mother (in years) } \\
\hline$<20$ & $5(50 \%)$ & $5(50 \%)$ & \multirow{3}{*}{2.40} & \multirow{3}{*}{$0.30 *$} \\
\hline $21-30$ & $52(42.6 \%)$ & $70(57.4 \%)$ & & \\
\hline$>30$ & $19(57.6 \%)$ & $14(42.4 \%)$ & & \\
\hline \multicolumn{5}{|c|}{ Age of Child (in years) } \\
\hline$<1$ & $7(35 \%)$ & $13(65 \%)$ & \multirow{4}{*}{3.18} & \multirow{4}{*}{$0.36 *$} \\
\hline $1-2$ & $22(52.4 \%)$ & $20(47.6 \%)$ & & \\
\hline $3-4$ & $30(41.7 \%)$ & $42(58.3 \%)$ & & \\
\hline 5 & $17(54.8 \%)$ & $14(45.2 \%)$ & & \\
\hline \multicolumn{5}{|c|}{ Education status } \\
\hline $\begin{array}{l}\text { No formal } \\
\text { education }\end{array}$ & $4(100 \%)$ & 0 & \multirow{6}{*}{15.99} & \multirow{6}{*}{0.007} \\
\hline $\begin{array}{l}\text { Primary } \\
\text { education }\end{array}$ & $22(57.9 \%)$ & $16(42.1 \%)$ & & \\
\hline $\begin{array}{l}\text { Secondary } \\
\text { education }\end{array}$ & $27(52.9 \%)$ & $24(47.1 \%)$ & & \\
\hline $\begin{array}{l}\text { Higher } \\
\text { secondary } \\
\text { education }\end{array}$ & $17(36.2 \%)$ & $30(63.8 \%)$ & & \\
\hline $\begin{array}{c}\text { Under } \\
\text { graduation }\end{array}$ & $6(30 \%)$ & $14(70 \%)$ & & \\
\hline $\begin{array}{l}\text { Post graduate } \\
\text { and above }\end{array}$ & 0 & $5(100 \%)$ & & \\
\hline \multicolumn{5}{|c|}{ Occupational Status } \\
\hline House wife & $45(50 \%)$ & $45(50 \%)$ & \multirow{6}{*}{14.88} & \multirow{6}{*}{0.01} \\
\hline $\begin{array}{c}\text { Government } \\
\text { employed }\end{array}$ & $1(20 \%)$ & $4(80 \%)$ & & \\
\hline $\begin{array}{l}\text { Private } \\
\text { employed }\end{array}$ & $4(18.2 \%)$ & $18(81.8 \%)$ & & \\
\hline Self employed & $14(58.3 \%)$ & $10(41.7 \%)$ & & \\
\hline Daily wages & $7(77.8 \%)$ & $2(22.2 \%)$ & & \\
\hline Agriculture & $5(33.3 \%)$ & $10(66.7 \%)$ & & \\
\hline
\end{tabular}




\begin{tabular}{|c|c|c|c|c|}
\hline \multicolumn{5}{|c|}{ Family Income per month (in Rs) } \\
\hline$<10,000$ & $9(75 \%)$ & $3(25 \%)$ & \multirow{4}{*}{14.91} & \multirow{4}{*}{0.002} \\
\hline $\begin{array}{c}10,001- \\
20,000\end{array}$ & $29(60.4 \%)$ & $19(39.6 \%)$ & & \\
\hline $\begin{array}{c}20,001- \\
30,000\end{array}$ & $27(42.9 \%)$ & $36(57.1 \%)$ & & \\
\hline $\begin{array}{c}30,001 \text { and } \\
\text { above }\end{array}$ & $11(26.2 \%)$ & $31(73.8 \%)$ & & \\
\hline \multicolumn{5}{|c|}{ Type of family } \\
\hline Nuclear & $48(47.1 \%)$ & $54(52.9 \%)$ & \multirow{2}{*}{0.10} & \multirow{2}{*}{$0.74^{*}$} \\
\hline Joint & $28(44.4 \%)$ & $35(55.6 \%)$ & & \\
\hline \multicolumn{5}{|c|}{ No of under five children } \\
\hline One child & $47(47 \%)$ & $53(53 \%)$ & \multirow{3}{*}{2.82} & \multirow{3}{*}{$0.24^{*}$} \\
\hline Two & $25(41.7 \%)$ & $35(58.3 \%)$ & & \\
\hline $\begin{array}{c}\text { Three and } \\
\text { above }\end{array}$ & $4(80 \%)$ & $1(20 \%)$ & & \\
\hline \multicolumn{5}{|c|}{ Previous Source of Information } \\
\hline $\begin{array}{l}\text { No source of } \\
\text { information }\end{array}$ & $14(87.5 \%)$ & $2(12.5 \%)$ & \multirow{4}{*}{15.50} & \multirow{4}{*}{0.001} \\
\hline $\begin{array}{c}\text { Family, Friends, } \\
\text { Neighbors }\end{array}$ & $30(46.2 \%)$ & $35(53.8 \%)$ & & \\
\hline $\begin{array}{c}\text { Newspaper, } \\
\text { Magazine }\end{array}$ & $5(23.8 \%)$ & $16(76.2 \%)$ & & \\
\hline $\begin{array}{l}\text { TV, Radio, } \\
\text { Internet }\end{array}$ & $27(42.9 \%)$ & $36(57.1 \%)$ & & \\
\hline \multicolumn{5}{|c|}{ Child Ever Faced an Emergencies } \\
\hline Yes & $28(45.2 \%)$ & $34(54.8 \%)$ & \multirow[t]{2}{*}{0.32} & \multirow[t]{2}{*}{$0.85^{*}$} \\
\hline No & $48(46.6 \%)$ & $55(53.4 \%)$ & & \\
\hline
\end{tabular}

(*Statistically not significant at $5 \%$ level of significance, chi square was computed for $P$ value)

\section{DISCUSSION}

Demographic characteristic reveals highest percentage $(73.9 \%)$ of mothers were between the age group of 21 - 30 years. This finding is similar to national population and housing census. ${ }^{4}$ Age wise distribution of child reveals that $(43.6 \%)$ mothers had child in the age group of 3- 4 years. It is supported by the study conducted by Erkal S. who reported that most of the childhood injuries occur especially among children of 3-5 years because they are not aware of hazards and are more susceptible to the environmental risks. ${ }^{5}$
The highest percentage (30.9\%) of the mothers had secondary school education. The highest percentage $(54.5 \%)$ of the mothers were housewives and the result is supported by the study conducted by Kafle, who reported that most of the Nepalese women are housewives. ${ }^{6}$ Types of family wise distribution reveals that $(61.8 \%)$ mothers belongs to the nuclear family. However it is lowest when compare to the Nepal annual household survey in 2015/16. ${ }^{7}$ Most of the mothers $(60.6 \%)$ were with one under five children. This is supported by the study conducted by Ummuhan A, who reported that most mothers $57.1 \%$ were with one under five children. ${ }^{8}$

Item wise distribution of mean and SD of knowledge scores shows that out of the eight items related to pediatric first aid management reveals that, highest mean score in the area of "Bites and Stings" $(4.9 \pm 0.95)$. It is supported by K Maheswari. ${ }^{9}$ However lowest mean score was obtained for "Prevention and complication" $(1.47 \pm 0.84)$.

There is significant association between knowledge of pediatric first aid management and education status $(\mathrm{P}=0.007)$, occupational status ( $\mathrm{P}=0.01)$, family income $(\mathrm{P}=0.002)$ and the previous source of information $(\mathrm{P}=0.001)$. There is no significant association between knowledge score when compare to their age of mothers $(\mathrm{P}=$ $0.30)$, Age of child $(P=0.36)$, Number of underfive child ( $P=0.24){ }^{10}$ Types of family $(P=0.74)$. ${ }^{9}$ This findings supported with the similar study done by Maheswari $\mathrm{K}^{9}$ and Janaki Patal. ${ }^{10}$

\section{CONCLUSIONS}

The findings of the study shows that most of the respondents $76(46.1 \%)$ have inadequate knowledge about pediatric first aid management out of which highest mean score is in the area of "Bites and Stings". There is significant 
association between knowledge of pediatric first aid management and education status $(P$ $=0.007)$, occupational status $(P=0.01)$, family income $(\mathrm{P}=0.002)$ and the previous source of information $(\mathrm{P}=0.001)$. The paediatric nurses should understand the importance to enhance the knowledge of the mothers regarding the pediatric first aid health information to save the children and reduce under-five mortality rate.

\section{REFERENCES}

1. UNICEF. Population Division Levels and Trends in Child mortality report of Nepal.2013. Available from: https://www. unicef.org/media/files/2013_IGME_child_ mortality_Report.pdf

2. Safe kids worldwide. Report to the nation of USA.2013.Available from: https://www. safekids.org/sites/default/files/documents/ ResearchReports/report_to_the_nation_ protecting_children_in_your_home.pdf

3. Rezapur-ShahkolaiF, NaghaviM,Shokouhi M, Laflamme L. Unintentional injuries in the rural population of Twiserkan, Iran: A cross-sectional study on their incidence, characteristics and preventability. BMC Public Health. 2008;8(1).

4. National Population and Housing Census. National Planning Commission Secretariat, Central Bureau of Statistics, Government of Nepal, Vol 1, 2011. Available from: [https:// unstats.un.org/unsd/demographic-social/ census/documents/Nepal/Nepal-Census2011-Vol1.pdf]

5. Erkal S. Identification of the number of home accidents per year involving children in the 0-6 age group and the measures taken by mothers to prevent home accidents. Turk J Pediatr. 2010; 52(2):150-157. PMID: 20560250.
6. Kafle B, Yadav U, Marahatta S, Mishra D, Pant N. Unintentional Injuries among Under- Five Children in Mid- Western Nepal. JNPS [Internet]. 19Nov.2018;38(1):46-2. Available from: https:/www.nepjol.info/index.php/JNPS/ article/view/18250

7. Nepal Annual Household Survey. National Planning Commission Secretariat, Central Bureau of Statistics, Government of Nepal,2016. Available from: https:// reliefweb.int/sites/reliefweb.int/files/ resources/Annual\%20Household \%20 Survey\%202015_16_Major\%20findings.pdf

8. Ummuhan Akturk, Behice Erci. Determination of Knowledge, Attitudes and Behaviors Regarding Factors Causing Home Accidents and Prevention in Mothers with a Child Aged 0-5 Years. Journal of Education and Practice. 2016;7(18).

9. Maheswari K. Knowledge of mothers regarding first aid. Asian Journal of Nursing Education and Research.2017 Jan;7(1). Available from: https://ajner.com/ AbstractView.aspx?PID=2017-7-1-2

10. Janaki Patal, Arpan Pandya, Ravindra HN. Knowlwdge regarding Prevention of Childhood Accidents Among Mothers Of Under Five Years Children At Pipara, Vadodara. Journal of Nursing and Health Science.2014 Sep;3(5). 72-79.

Citation: Dhanasekaran N, Indhumathi L, Kharel A. Knowledge on Pediatric First Aid Management Among Mothers with Under Five Children in Bharatpur. JCMS Nepal. 2021 ; 17(1); 30-35. 